\title{
METODE PENGGUNAAN MEDIA PEMBELAJARAN
}

\author{
Maimunah \\ Dosen Manajemen Pendidikan Islam \\ Fakultas Ilmu Agama Islam, Universitas Islam Indragiri
}

\begin{abstract}
Abstrak
Metode penggunaan media pembelajaran adalah suatu cara yang ditempuhdalam mencapai tujuan pembelajaran yang sudah di desain dan terencana untuk kepentingan pebelajaran atau strategi dalam merancang media pembelajaran yang akan diberikan pada siswa, dan seorang guru harus mampu mengindentifikasi berbagai karakteristik media pembelajaran yang digunakan, Apakah media yang yang digunakan sesuai dengan karakteristik materi pelajaran yang akan diberikan. Artinya media pembelajaran tersebut dapat menunjang kelancaran proses pembelajaran sehingga siswa dapat mengikuti pembelajaran dengan baik dan bermakna.
\end{abstract}

Kata Kunci : Metode, Media, Pembelajaran.

\section{A. Pendahuluan}

Siswa memiliki berbagai keunikan dan keberagaman dalam menangkap informasi atau materi pelajaran yang diberikan oleh guru di dalam kegiatan pembelajaran. Ada tiga tipe bentuk penerimaan oleh siswa dalam kaitannya dengan penerimaan informasi atau materi yang diberikan guru.

Pertama, auditif, yaitu siswa yang senang mendengarkan penjelasan dari guru. Untuk tipe ini tanpa menggunakan media 
pembelajaran pun siswa tersebut dapat menangkap informasi atau materi pelajaran yang disampaikan guru.

Kedua, visual, siswa lebih senang melihat ketimbang mendengarkan. Untuk tipe ini, siswa akan berakibat kurang optimal menyerap informasi atau materi pelajaran bila guru hanya menggunakan verbal simbol atau ceramah. Penggunaan media pembelajaran adalah solusi yang tepat untuk siswa tipe visual ini. Karena dengan media pembelajaran, informasi yang disampaikan menjadi lebih konkret.

Ketiga, kinestetik, yaitu siswa yang senangnya melakukan (learning by doing). Untuk tipe ini penggunaan media pembelajaran dapat membantu keterserapan materi pelajaran yang diberikan guru, terutama berkenaan dengan demonstrasi yang difasilitasi oleh penggunaan media pembelajaran.

Jadi, bila guru telah melakukan kegiatan pembelajaran hanya menggunakan verbal symbol atau one way communication, ini belumlah optimal dalam mencapai kompetensi yang diharapkan. Hasil penelitian BAVA di Amerika Serikat menegaskan bahwa bila seorang guru atau tenaga pendidik yang mengajar hanya menggunakan verbal symbol (ceramah murni), maka materi yang terserap hanya $13 \%$ dan itu pun tidak akan bertahan lama, sementara yang menggunakan multimedia bisa mencapai 64 sampai $84 \%$ dan bertahan lama. Hal ini menunjukkan bahwa penggunaan media sangatlah besar pengaruhnya 
dalam meningkatkan perhatian, motivasi, dan peningkatan kualitas pembelajaran. ${ }^{1}$

\section{B. Pengertian Media Pembelajaran}

Kata media berasal dari bahasa latin dan merupakan bentuk jamak dari kata medium yang secara harfiah dapat diartikan sebagai 'perantara'. Menurut Heinich, Molenda, dan Russel (1990) Media is a channel of communication. Derived from the Latin word for "between", the term refers "to anything that carries information between a source and a receiver. ${ }^{2}$

Lesle J. Briggs (1979) menyatakan bahwa media pembelajaran sebagai "the physical means of conveying instructional content . . . . . . ... book, films, videotapes, ect. Lebih jauh Briggs menyatakan media adalah "alat untuk memberi perangsang bagi peserta didik supaya terjadi proses belajar. Sementara itu, mengenai efektivitas media, Brown (1970) menggarisbawahi bahwa media yang digunakan guru atau siswa dengan baik dapat mempengaruhi efektivitas program belajar mengajar. ${ }^{3}$

Dari pendapat di atas, dapat dikembangkan beberapa pemahaman tentang posisi media serta peran dan konstribusinya dalam kegiatan pembelajaran ataupun kegiatan pendidikan dan pelatihan. Beberapa pemahaman itu antara lain sebagai berikut.

\footnotetext{
${ }^{1}$ Rusman, Manajemen Kurikulum, Cet.1, (Jakarta :PT Rajagrafindo Persada, 2009), h. 151.

${ }^{2}$ Ibid.

${ }^{3}$ Ibid.
} 
1. Media merupakan wadah daripesan yang oleh sumber pesan ataupun penyalurnya ingin diteruskan kepada sasaran atau penerima pesan tersebut.

2. Aplikasi media pembelajaran berpijak pada kaidah ilmu komunikasi, yang antara lain dikatakan Lasswell (1982) "who says what in which channels to whom in what effect." Paradigma komunikasi tersebut meliputi lima hal berikut..

a. Who, siapa yang menyatakan? (guru, pengirim pesan).

b. What, pesan atau ide / gagasan apa yang disampaikan (dalam kegiatan pembelajaran ini berarti bahan ajar atau materi yang akan disampaikan).

c. Which channels, dengan saluran apa, media saluran apa, media atau sarana apa, pesan itu ingin disampaikan.

d. To whom, kepada siapa (sasaran, siswa, peserta didik).

e. What effect, dengan hasil atau dampak apa ?

Dari unsur-unsur di atas, tampaknya yang menjadi target atau tujuan dari suatu kegiatan pembelajaran adalah dampak atau hasil yang ingin dicapai dalam suatu kegiatan pembelajaran. Dalam kajian kependidikan, istilah itu dikenal dengan nama "meaningful learning experience”, yaitu suatu pengalaman belajar yang bermakna sebagai hasil dari suatu pembelajaran (instruction).

Proses belajar mengajar hakikatnya adalah proses komunikasi, di mana guru berperan sebagai pengantar pesan dan siswa sebagai penerima pesan. Pesan yang dikirimkan oleh guru berupa isi / ajaran

${ }^{4}$ Ibid., h. 152. 
yang dituangkan ke dalam simbol-simbol komunikasi baik verbal (katakata dan tulisan) maupun nonverbal, proses ini dinamakan encoding. Penafsiran simbol-simbol komunikasi tersebut oleh siswa dinamakan decoding.

Namun, bagaimana bentuk dan wujud media atau perantara ini, hal tersebut harus disesuaikan dengan jenis dan karakteristik materi yang akan disampaikan serta kemampuan guru tentang pengetahuannya mengenai media.sebagai contoh dalam proses pembelajaran, hal yang harus diperhatikan ketika penyampaian materi / informasi berlangsung adalah keluasan, kedalaman dari materi pelajaran, selain itu juga waktu yang diperlukan untuk mengajakan materi tersebut, dan kondisi yang tersedia di sekolah sehingga media menjadi efektif digunakan dalam proses pembelajaran.

Selain sebagai perantara dalam interaksi belajar mengajar, media pembelajaran memiliki peran sebagai alat bantu proses belajar mengajar yang efektif. Proses belajar mengajar sering kali ditandai dengan adanya unsur tujuan, bahan, metode, dan alat, serta evaluasi. Keempat unsur tersebut saling berinteraksi dan berinterelasi. Metode dan media merupakan unsur yang tidak dapat dipisahkan dari unsur pembelajaran yang lain. Metode dan alat yang dalam hal ini adalah media pembelajaran berfungsi untuk menyampaikan materi pembelajaranagar sampai kepada tujuan. Dengan menggunakan media pembelajaran diharapkan siswa dapat memperoleh berbagai pengalaman nyata sehingga materi pelajaran yang disampaikan dapat diserap dengan mudah dan lebih baik. 
Penggunaan media dalam pembelajaran didasarkan pada konsep bahwa belajar dapat ditempuh melalui berbagai cara, antara lain dengan mengalami secara langsung (melakukan dan berbuat), dengan mengamati orang lain, dan dengan membaca serta mendengar. Olsen mengungkapkan bahwa prosedur belajar dapat ditempuh dalam tiga tahap, yaitu (1) pembelajaran langsung melalui pengalaman langsung, pembelajaran ini diperoleh dengan teknik karyawisata, wawancara, resource visito; (2) pembelajaran tidak langsung, dapat melalui alat peraga atau media pembelajaran, pengalaman ini diperoleh melalui gambar, peta, bagan, objek, slide, film, TV, LCD, dramatisasi, dan lainlain; (3) pembelajaran tidka langsung melalui lambang kata, misalnya melalui kata-kata (simbol verbal), dan rumus-rumus yang digunakan dalam kegiatan pembelajaran. ${ }^{5}$

\section{Kedudukan Media dalam Pembelajaran}

Kedudukan media dalam komponen pembelajaran sangat penting bahkan sejajar dengan metode pembelajaran, karena metode yang digunakan dalam proses pembelajaran biasanya akan menuntut media apa yang digunakan dapat diintegrasikan dan diadaptasikan dengan kondisi yang dihadapi. Maka, kedudukan media dalam suatu pembelajaran sangatlah penting dan menentukan.

Jika kembali kepada paradigma pembelajaran sebagai suatu proses transaksional dalam menyampaikan pengetahuan, keterampilan, dan psikomotor, maka posisi media jika diilustrasikan dan disejajarkan

5 Iskandar Agung, Meningkatkan Kreativitas Pembelajaran Bagi Guru, (Jakarta Timur: Bestari Byauna Murni, 2010), h.33. 
dengan proses komunikasi yang terjadi, berikut ini adalah gambar yang menunjukkan posisi dari media dalam suatu proses yang bisa dikatakan sebagai proses komunikasi maupun proses pembelajaran.

Dalam proses pembelajaran terdapat tingkatan proses aktivitas yang melibatkan keberadaan media pembelajaran, yaitu (1) tingkat pengolahan informasi; (2) tingkat penyampaian informasi; (3) tingkat penerimaan informasi; (4) tingkat pengolahan informasi; (5) tingkat respons dari siswa; (6) tingkat diagnosis dari guru; (7) tingkat penilaian; (8) tingkat penyampaian hasil.

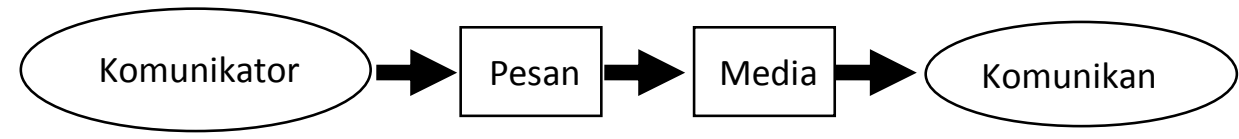

Terjadinya pengalaman belajar yang bermakna ini tidak terlepas dari peran media, terutama dari kedudukan dan fungsinya. Secara umum media mempunyai kegunaan :

1. Memperjelas pesan agar tidak terlalu verbalistis;

2. Mengatasi keterbatasan ruang, waktu, tenaga, dan daya indra;

3. Menimbulkan gairah belajar, interaksi lebih langsung antara murid dengan sumber belajar;

4. Memungkinkan anak belajar mandiri sesuai dengan bakat dan kemampuan visual, auditori, dan kinestiknya;

5. Memberi rangsangan yang sama, mempersamakan pengalaman, dan menimbulkan presepsi yang sama.

Kontribusi media terhadap pembelajaran menurut Kemp and Dayton, (1985:24), adalah (1) penyampaian pesan pembelajaran dapat lebih terstandar; (2) pembelajaran dapat lebih menarik; (3) pembelajaran menjadi lebih interaktif dengan menerapkan teori belajar; 
(4) waktu pelaksanaan pembelajaran dapat diperpendek; (5) kualitas pembelajaran dapat ditingkatkan; (6) proses pembelajaran dapat berlangsung kapan pun dan di mana pun diperlukan; (7) sikap positif siswa terhadap materi pembelajaran serta proses pembelajaran dapat ditingkatkan; (8) peran guru berubah ke arah yang positif.

Peranan media dalam proses pembelajaran dapat ditempatkan sebagai berikut. (1) alat untuk memperjelas bahan pembelajaran pada saat guru menyampaikan pelajaran. Dalam hal ini media digunakan guru sebagai variasi penjelasan verbal mengenai bahan pembelajaran; (2) alat untuk mengangkat atau menimbulkan persoalan untuk dikaji lebih lanjut oleh para siswa dalam proses belajarnya. Paling tidak guru dapat menempatkan media sebagai sumber pertanyaan atau stimulasi belajar siswa; (3) sumber belajar bagi siswa, artinya media tersebut berisikan bahan-bahan yang harus dipelajari para siswa baik secara individual maupun kelompok. Dengan demikian, akan banyak membantu tugas guru dalam kegiatan mengajarnya.

Karakteristik dan kemampuan masing-masing media perlu diperhatikan oleh guru agar mereka dapat memilih media mana yang sesuai dengan kondisi dan kebutuhan. Sebagai contoh media audio, merupakan media auditif yang mengajarkan topik-topik pembelajaran yang bersifat verbal seperti pengucapan (pronounciation) bahasa asing. Untuk pembelajaran bahasa asing media ini tergolong tepat karena bila secara langsung diberikan tanpa media sering terjadi katidaktepatan dalam pengucapan pengulangan dan sebagainya. Pembuatan media audio ini termasuk mudah, hanya membutuhkan alat perekam dan 
narasumber yang dapat berbahasa asing, sementara itu pemanfaatannya menggunakan alat yang sama pula.

Media pembelajaran harus meningkatkan motivasi siswa. Penggunaan media mempunyai tujuan memberikan motivasi kepada siswa. Selain itu, media juga harus merangsang siswa mengingat apa yang sudah dipelajari selain memberikan rangsangan belajar baru. Media yang baik juga akan mengaktifkan siswa dalam memberikan tanggapan, umpan balik, dan juga mendorong mahasiswa untuk melakukan praktik-praktik dengan benar.

Menurut Hubbard (1983), ada sembilan kriteria untuk menilai keefektifansebuah media, yaitu biaya, ketersediaan fasilitas pendukung, kecocokan dengan ukuran kelas, keringkasan, kemampuan untuk diubah, waktu dan tenaga penyiapan, pengaruh yang ditimbulkan, kerumitan, dan kegunaan. Berikut adalah beberapa kriteria pemilihan media pembelajaran.

1. Ketepatannya dengan tujuan pembelajaran; artinya media pembelajaran dipilih atas dasar tujuan-tujuan pembelajaran atau kompetensi yang telah ditetapkan.

2. Dukungan terhadap isi materi pelajaran; artinya bahan pelajaran yang sifatnya fakta, prinsip, konsep, dan generalisasi sangat memerlukan bantuan media agar lebih mudah dipahami siswa.

3. Kemudahan mendapatkan media; artinya media yang diperlukan mudah diperoleh, setidak-tidaknya mudah dibuat oleh guru pada saat pembelajaran. 
4. Keterampilan guru menggunakannya; artinya secanggih apa pun sebuah media apabila tidak tahu cara menggunakannya, maka media tersebut tidak memiliki arti apa-apa.

5. Tersedia alokasi waktu untuk menggunakannya sehingga media tersebut dapat bermanfaat bagi siswa selama proses pembelajaran berlangsung.

6. Memilih media pembelajaran harus sesuai dengan taraf berpikir dan perkembangan siswa sehingga makna yang terkandung di dalamnya dapat dipahami dan mudah dimengerti oleh para siswa.

Sebagai contoh, media kaset audio merupakan media auditif yang mengajarkan topik-topik pembelajaran yang bersifat verbal seperti pengucapan (pronounciation) bahasa Inggris. Untuk pembelajaran bahasa Inggris, media ini tergolong tepat karena bila secara langsung diberikan tanpa media, sering terjadi ketidaktepatan yang akurat dalam pengucapan pengulangan, artikulasi, dan sebagainya. Pembuatan media kaset audio ini termasuk mudah, hanya membutuhkan alat perekam dan narasumber yang dapat berbahasa Inggris, sementara itu, pemanfaatannya menggunakan alat yang sama pula.

\section{Jenis-jenis Media Pembelajaran}

Secara umum klasifikasi media pembelajaran dikategorikan ke dalam tiga unsur poko, yaitu audio, visual, dan gerak. Menurut Rudy Brets terdapat tujuh kalsifikasi media pembelajaran, yaitu (1) media audio visual gerak; (2) media audio visual diam; (3) audio semi gerak; 
(4) media visual bergerak; (5) media visual diam; (6) media audio; dan (7) media cetak. ${ }^{6}$

Sementara Wilbum Schramm, mengelompokkan media dengan membedakan antara media modern (big media) dan media sederhana (little media). Kategori big media, antara lain komputer, film, slide, program video. Sementara itu, little media antara lain gambar, relia sederhana, sketsa, bagan, poster, dan lain-lain. Klasek membagi media pembelajaran sebagai berikut : (1) media visual; (2) media audio; (3) media "display"; (4) pengalaman nyata dan simulasi; (5) media cetak; (6) belajar terprogram; (7) pembelajaran melalui komputer latau sering dikenal Computer Assisted Instuction (CAI) dan pembelajaran berbasis komputer atau Computer Based Instruction (CBI).

Secara sederhana kehadiran media dalam suatu kegiatan pembelajaran memiliki nilai-nilai praktis sebagai berikut :

1. Media pembelajaran dapat mengatasi keterbatasan pengalaman yang dimiliki para siswa.

2. Media yang disajikan dapat melampaui batasan ruang kelas.

3. Media pembelajaran memungkinkan adanya interaksi antara peserta didik dengan lingkungannya.

4. Media yang disajikan dapat menghasilkan keseragaman pengamatan siswa.

5. Secara potensial, media yang disajikan secara tepat dapat menanamkan konsep dasar yang konkret, benar, dan berpijak pada realitas.

6 Trianto, Mendesain Model Pembelajaran Inovatif-progresif, (Jakarta: Kencana, 2010), h. 17. 
6. Media dapat membangkitkan keinginan dan minat baru.

7. Media mampu membangkitkan motivasi dan merangsang peserta didik untuk belajar.

8. Media mampu memberikan belajar secara integral dan menyeluruh dari yang konkret ke yang abstrak, dari sederhana ke rumit. ${ }^{7}$

Dari semua itu, kemudian dikembangkan media dalam suatu konsepsi teknologi pembelajaran yang memiliki ciri : (a) berorientasi pada sasaran (target oriented); (b) menerapkan konsep pendekatan sistem; (c) memanfaatkan sumber belajar yang bervariasi. Dengan demikian, aplikasi media dan teknologi pendidikan, bisa merealisasikan suatu konsep "teaching less learning more”. Artinya secara aktivitas fisik bisa saja aktivitas kegiatan guru di kelas dikurangi, karena ada sebagian tugas guru yang didelegasikan pada media, namun tetap mengusung tercapainya produktivitas belajar siswa.

Pengelompokan media juga dikemukakan oleh Anderson, yaitu sebagai berikut. ${ }^{8}$

\begin{tabular}{|c|c|c|}
\hline No. & Kelompok Media & Jenis Media \\
\hline 1 & Audio & $\begin{array}{ll}\text { - } & \text { Pita Audio (kaset) } \\
\text { - } & \text { Piringan Audio } \\
\text { - } & \text { Radio (rekaman siaran) } \\
\end{array}$ \\
\hline 2 & Cetak & $\begin{array}{ll}\text { - } & \text { Buku Teks Terprogram } \\
\text { - } & \text { Buku Pegangan / Manual } \\
\text { - } & \text { Buku Tugas } \\
\end{array}$ \\
\hline 3 & Audio - Cetak & $\begin{array}{l}\text { - Buku Latihan dilengkapi } \\
\text { kaset }\end{array}$ \\
\hline
\end{tabular}

\footnotetext{
${ }^{7}$ Rusman, Manajemen...., h. 156.

${ }^{8}$ Ibid,h. 157
} 


\begin{tabular}{|c|c|c|}
\hline & & $\begin{array}{l}\text { - Gambar / poster (dilengkapi } \\
\text { audio) }\end{array}$ \\
\hline 4 & Proyek Visual Diam & $\begin{array}{ll}\text { - } & \text { Film bingkai (slide) } \\
\text { - } & \text { Film rangkai (berisi pesan } \\
& \text { verbal) }\end{array}$ \\
\hline 5 & $\begin{array}{l}\text { Proyek Visual Diam } \\
\text { dengan Audio }\end{array}$ & $\begin{array}{l}\text { - Film bingkai (slide) suara } \\
\text { - Film rangkai suara }\end{array}$ \\
\hline 6 & Visual Gerak & - Film bisu \\
\hline 7 & $\begin{array}{l}\text { Visual Gerak dengan } \\
\text { Audio }\end{array}$ & $\begin{array}{ll}\text { - } & \text { Film suara } \\
\text { - } & \text { Video / VCD / DVD }\end{array}$ \\
\hline 8 & Benda & $\begin{array}{ll}\text { - } & \text { Benda nyata } \\
\text { - } & \text { Model tiruan (mock up) }\end{array}$ \\
\hline 9 & Komputer & $\begin{array}{l}\text { Media berbasis Komputer: } \\
\text { Computer Assisted } \\
\text { Instruction (CAI) dan } \\
\text { Computer Based Instruction } \\
\text { (CBI) }\end{array}$ \\
\hline
\end{tabular}

\section{E. Prosedur Pemilihan Media}

Ada beberapa prinsip yang perlu diperhatikan dalam pemilihan media pembelajaran, meskipun caranya berbeda-beda. Namun demikian, ada hal yang seragam bahwa setiap media pembelajaran memiliki kelebihan dan kekurangan yang akan memberikan pengaruh kepada afektivitas program pembelajaran.

Sejalan dengan ini, pendekatan yang ditempuh adalah mengkaji media pembelajaran sebagai bagian integral dalam proses pendidikan yang kajiannya akan sangat dipengaruhi oleh beberapa hal berikut.

Pertama, tujuan atau kompetensi apa yang akan dicapai dalam suatu kegiatan pembelajaran. Dari kajian tujuan ini bisa dianalisis media apa yang cocok untuk mencapai tujuan tersebut. 
Kedua, materi pembelajaran (instructional content), yaitu bahan atau kajian apa yang akan diajarkan pada program pembelajaran tersebut. Pertimbangan lainnya, dari bahan atau pokok bahasan tersebut sampai sejauh mana kedalaman yang harus dicapai. Dengan demikian, kita bisa mempertimbangkan media apa yang sesuai untuk penyampaian bahan tersebut.

Ketiga, familiaritas media dan karakteristik siswa / guru, yaitu mengkaji sifat-sifat dan ciri media yang akan digunakan. Hal lainnya karakteristik siswa, baik secara kuantitatif (jumlah) ataupun kualitatif (kualitas, cicir, dan kebiasaan lain) dari siswa terhadap media yang kan digunakan.

Keempat, adanya sejumlah media yang bisa diperbandingkan karena pemilihan media pada dasarnya adalah proses pengambilan keputusan dari jumlah media yang ada ataupun yang akan didesain atau dikembangkan. ${ }^{9}$

Menurut Erickson dalam mengembangkan kreteria pemilihan media sebaikknya dalam bentuk pertanyaan sebagai berikut.

1. Apakah materinya penting dan berguna bagi siswa ?

2. Apakah dapat menarik minat siswa untuk belajar ?

3. Apakah ada kaitannya dan mengena secara langsung dengan tujuan pembelajaran?

4. Bagaimana format penyajiannya diatur ? Apakah memenuhi tata urutan yang teratur?

5. Bagaimana dengan materinya, mutakhir adan autentik?

${ }^{9}$ Ibid., h. 158. 
6. Apakah konsep dan kecermatannya terjamin ?

7. Apakah isi dan presentasenya standar?

8. Apakah penyajiannya objektif ?

9. Apakah bahannya memenuhi standar kualitas teknis ?

10. Apakah bahan tersebut sudah memlalu pemantapan uji coba atau validasi ?

Sementara itu, bila kita akan merancang atau mendesain media pembelajaran seharusnya melalui tiga tahapan berikut. Pertama, pembatasan (define), define), yaitu menyangkut rumusan tujuan atau kompetensi, rancangan media yang kan dikembangkan, beberapa persiapan awal dalam perancangan media yang menyangkut: kompetensi atau tujuan, materi/konten, dana, dan konsep aspek perancangan lainnya.

Kedua, pengembangan (develop), dalam tahap ini dimulai proses pembuatan media pembelajaran yang kan dikembangkan, sesuai dengan tahap pertama.

Ketiga, evaluasi (evaluation), yaitu tahap akhir untuk menilai media yang sudah diabut, setelah tahap uji coba, revisi, dan kajian dengan pihak lain. Untuk kemudian media pembelajaran diproduksi, langkah selanjutnya adalah menggunakan media pembelajaran tersebut.

Ilustrasi proses pemilihan media pembelajaran oleh Anderson dapat digambarkan dengan flowhart sebagai berikut. 
(1)

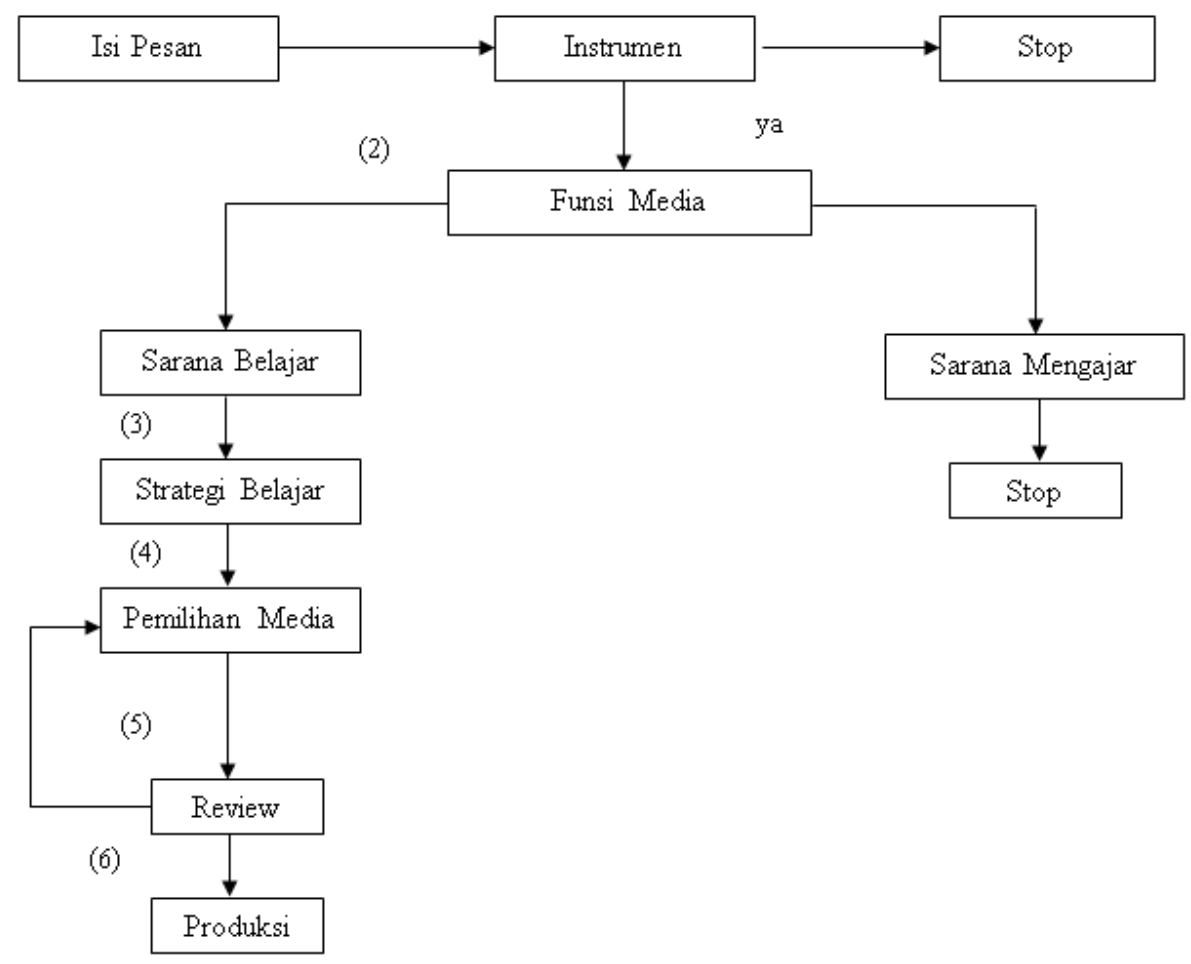

Selain pertimbangan di atas, konsep lain untuk memilih media pembelajaran dapat menggunakan pola lain. Sejumlah pertimbangan dalam memilih media pembelajaran yang tepat dapat mengggunakan akronim kata ACTION, yaitu : Access, Cost, Technoloy, Interativity, Organization, dan Novelty.

1. Acces. Kemudahan akses menjadi petimbangan pertama dalam memilih media. Apakah media yang kita perlukan itu tersedia, mudah, dan dapat dimanfaatkan oleh siswa? Misalnya, kita ingin menggunakan media internet, perlu dipertimbangkan terlebih dahulu apakah ada saluran untuk koneksi ke internet? Akses juga menyangkut aspek kebijakan, misalnya apakah murid diizinkan 
untuk menggunakannya? Komputer yang terhubung ke internit jangan hanya digunakan untuk kepala sekolah, tetapi juga guru, dan yang lebih penting untuk murid. Murid harus memperoleh akses.

2. Cost. Biaya juga harus dipertimbangkan. Banyak jenis media yang dapat menjadi pilihan kita. Multimedia biasanya mahal. Namun, mahalnya biaya itu harus kita hitung dengan aspek manfaatnya. Semakin banyak yang menggunakan, maka unit cots dari sebuah media akan semakin menurun.

3. Technology. Mungkin saja kita tertarik kepada satu media tertentu. Namun, perlu kita perhatikan apakah teknologinya tersedia dan mudah mengoperasikannya? Katakanlah kita ingin menggunakan media audio visual di kelas. Perlu kita pertimbangkan, apakah ada listrik, voltase listrik cukup dan sesuai?

4. Interactivity. Media yang baik adalah yang dapat memunculkan komunikasi dua arah (interaktivitas). Setiap kegiatan pembelajaran yang dikembangkan tentu saja memerlukan media yang sesuai dengan tujuan atau kompetensi pembelajaran tersebut.

5. Organization. Pertimbangan yang juga penting adalah dukungan organisasi. Misalnya, apakah pimpinan sekolah atau lembaganya mendukung? Bagaimana pengorganisasiannya? Apakah di sekolah ini tersedia pusat sumber belajar?

6. Novelty. Kebaruan dari media yang Anda pilih juga harus menjadi pertimbangan. Media yang lebih terkini biasanya lebih bvaik dan menarik bagi siswa. ${ }^{10}$

${ }^{10}$ Ibid., h. 160. 


\section{F. Karakteristik Media}

1. Media Grafis

Media cetak dan grafis di dalam proses pembelajaran paling banyak dan paling sering digunakan. Media ini termasuk katagori media visual nonproyeksi yang berfungsi untuk menyalurkan pesan dari pemberi ke penerima pesan atau dari guru kepada siswa. Pesan yang dituangkan dalam bentuk tulisan, huruf, gambar, dan simbol yang mengandung arti disebut "Media Grafis."

Media grafis termasuk media visual diam, sebagaimana halnya dengan media lain media grafis mempunyai fungsi untuk menyalurkan pesan dari guru kepada siswa. Saluran yang dipakai menyangkut indra penglihatan yang dituangkan ke dalam simbolsimbol yang menarik dan jelas.

Media ini termasuk media yang relatif murah dan mudah dalam pendanaannya bila ditimbang dari segi biaya. Macam-macam media grafis, yaitu gambar/foto, diagram, bagan, grafik, poster, media cetak, buku dan sebagainya.

2. Gambar / Foto

Media grafis paling umum digunakan dalam pembelajaran, karena merupakan bahasa yang umum dan dapat mudah dimengerti oleh peserta didik. Kemudahan mencerna media grafis karena sifatnya visual konkret menampilkan objek sesuai dengan bentuk dan wujud aslinya sehingga tidak verbalistrik.

Kelebihan media foto ialah : (1) sifatnya konkret, lebih realistisk dibandingkan dengan verbal simbol: (2) dapat memperjelas suatu masalah dalam bidang apa saja, baik untuk usia 
muda maupun tua: (3) murah harnya dan tidak memperluaskan peralatan khusus dalam penyampaiannya.

Sementara itu, kelemahan media foto, adalah : (1) gambar/foto hanya menekankan pada persepsi indra mata: (2) ukurannya sangat terbatas untuk kelompok besar: (3) tidak bisa menampilkan secara detail. Contoh gambar :

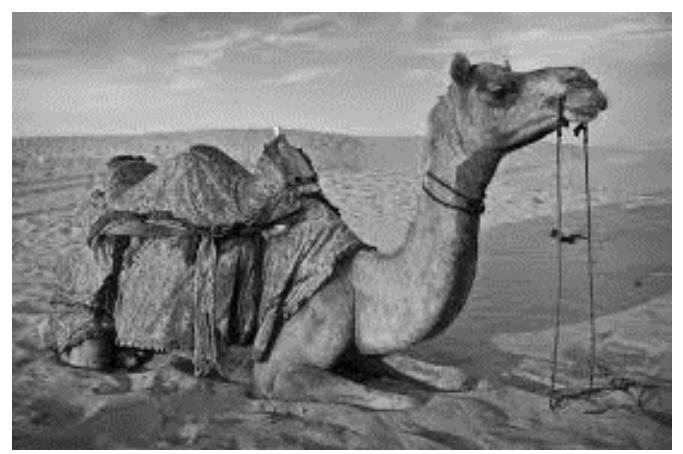

3. Diagram

Diagram merupakan gambar sederhana yang menggunakan garis-garis dan simbol-simbol secara garis besar dan menunjukkan hubungan antar komponen atau proses yang ada pada diagram tersebut. Isi diagram pada umumnya berupa petunjuk-petunjuk. Diagram ini berfungsi untuk menyederhanakan hal-hal yang komplek sehingga dapat memperjelas penyajian pesan. Diagram biasanya bersifat :

a. Simbolis dan abstrak, kadang-kadang sulit dimengerti

b. Untuk dapat membaca diagram diperlukan keahlian khusus dalam bidangnya tentang isi diagram tersebut

c. Walaupun sulit dimengerti, karena sifatnya yang padat diagram dapat memperjelas arti. 
Ciri-ciri diagram yang baik

a. Cukup rapi dan disertai dengan keterangan yang jelas

b. Cukup besar dan ditempatkan secara strategis

c. Penyusunannya disesuaikan dengan pola baca yang umum dari atas ke bawah atau kiri kekanan

d. Sesuai dengan kaidah keterbacaan visual.

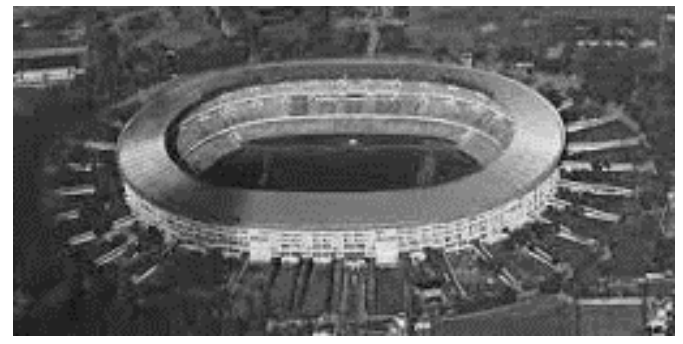

4. Bagan

Bagan merupakan media yang berisi gambar keterangan, daftar, dan sebaginya. Bagan digunakan untuk memperagamkan pokok-pokok isi bagasi secara jelas dan sederhana, antara lain: perkembangan, perbandingan, struktur, organisasi, dan langkahlangkah atau prosedur kerja. Jenis-jenis media bagan antara lain: 
tree chart dan flow chart. Untuk lebih jelas tentang contoh bagan dapat dilihat pada gambar berikut :

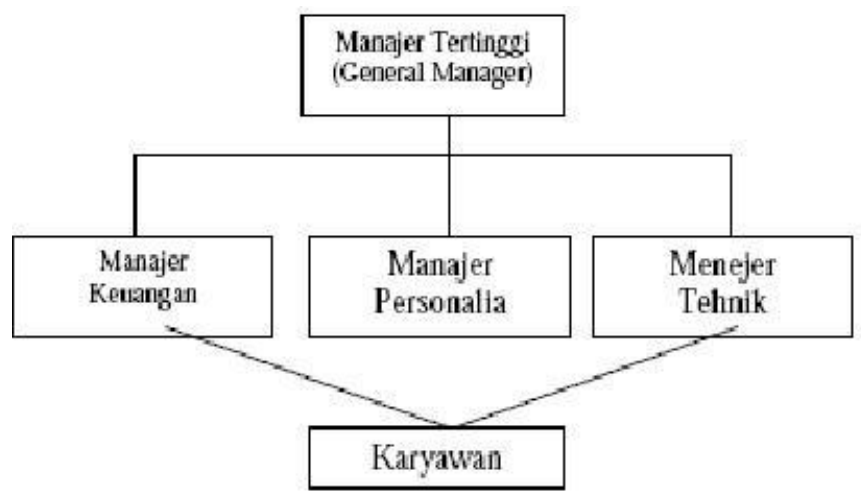

5. Garfik (Graph)

Grafik adalah penyajian kembali data-data yang berupa angka-angka dalam bentuk visual simbolis (lambang visual). Jenis grafik di antaranya adalah sebagai berikut.

a. Garik garis (line graph), line graph), yaitu grafik yang paling dapat menggambarkan data secara tepat, dapat menggambarkan hubungan antara dua kelompok data dan dapat digunakan untuk data-data yang kontinu.

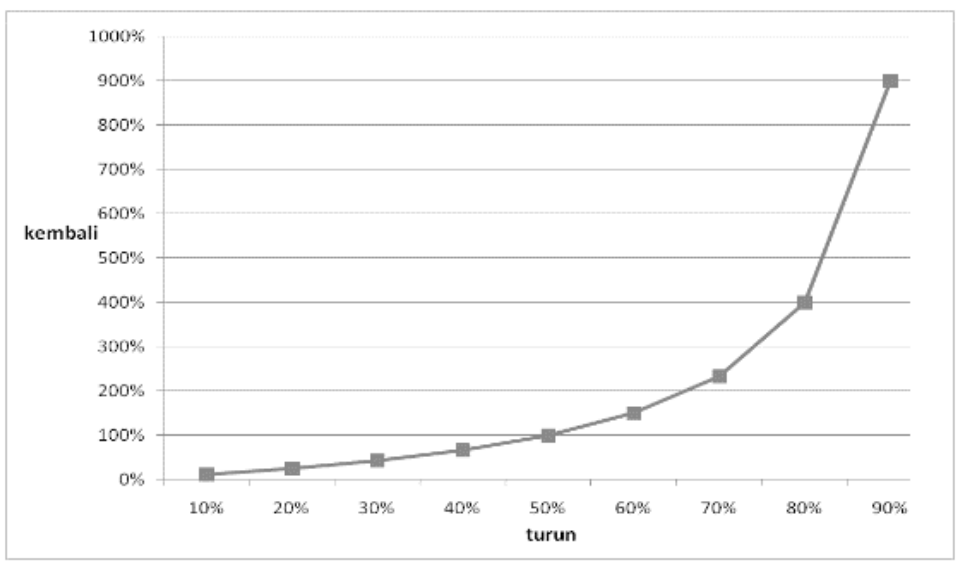


b. Grafik batang, yaitu grafik yang menggambarkan jumlah data. Beberapa hal yang perlu diperhatikan dalam grafik, yaitu: simbol gambar yang dipakai sendiri (self explantory), jumlah data yang diperhatikan melalui jumlah gambar, dan jumlah besar kecilnya gambar akan dapat dibaca apabila di bawah gambar tersebut diberikan angka yang sebenarnya.

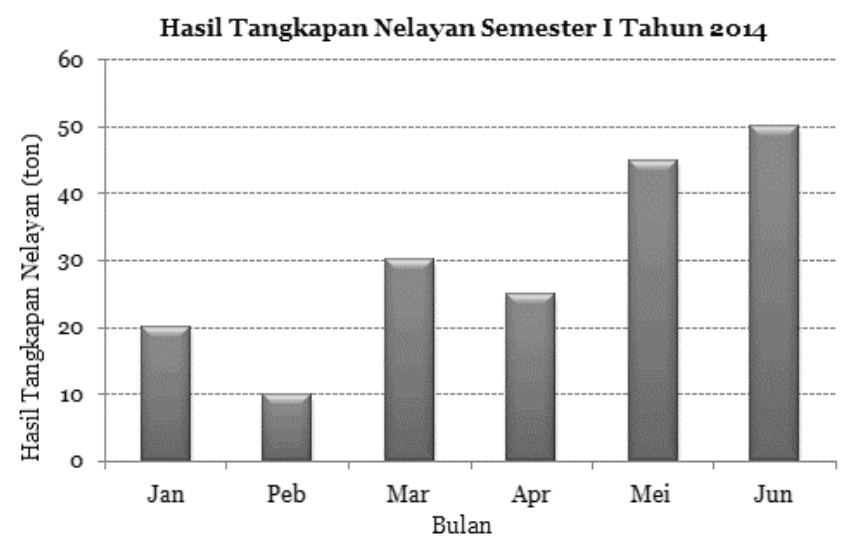

6. Media Display

\section{a. Papan Tulis / White Board}

Salah satu media penyajian pembelajaran yang juga sering digunakan adalah: papan tulis dan white board. Kedua media ini dapat dipakai untuk penyajian tulisan, sket, gambar dengan menggunakan kapur, pidol white board, baik yang bewarna ataupun tidak bewarna. Maksud dari warna tersebut adalah agar tulisan lebih jela, menarik, dan dapat berkesan bagi siswa yang akan menerimanya. ${ }^{11}$

${ }^{11}$ Ibid, h. 163 


\section{G. Penutup}

penggunaan media pembelajaran sangatlah besar pengaruhnya dalam meningkatkan perhatian, motivasi, dan peningkatan kualitas pembelajaran. Yang menjadi target atau tujuan dari suatu kegiatan pembelajaran adalah dampak atau hasil yang ingin dicapai dalam suatu kegiatan pembelajaran.Media pembelajaran memiliki peran sebagai alat bantu proses belajar mengajar yang efektif. Proses belajar mengajar sering kali ditandai dengan adanya unsur tujuan,bahan,metode, dan alat, serta evaluasi. Keempat unsur tersebut saling berintreaksi dan berintelerasi.Metode dan media merupakan unsur yang tidak dapat dipisahkan dari unsur-unsur pembelajaran yang lain.Metode dan alat adalah media pembelajaran yang berpungsi untuk menyampaikan materi pembelajaran agar sampai kepada tujuan. Dengan menggunakan Media pembelajaran diharapkan siswa dapat memperoleh pengalaman nyata sehingga materi pelajaran yang disampaikan dapat diserap dengan mudah dan lebih baik. 


\section{DAFTAR PUSTAKA}

Agung, Iskandar. 2010. Meningkatkan kreativitas pembalajaran bagi guru, Jakarta Timur Bistari Buana Murni.

Departemen Pendidikan Nasional. 2006. Peraturan Menteri Pendidikan Nasional Republik Indonesia, Jakarta: Tp.

Ibrahim, 1989. Inovasi Pendidikan, Jakarta: Grasindo.

Mulyasa. 2009. Implementasi Kurikulum Tingkat Satuan Pendidikan, Jakarta: Bumi Aksara.

An-Nahlawi, Abdurrahman. 1989. Prinsip-prinsip Dasar Metode Pendidikan dalam Keluarga di Sekolah dan di Masyarakat, Terj. Herry Noer Ali Bandung: Diponegoro.

Subroto, Suryo. 2005. Tata Laksana Kurikulum, Jakarta: Rineka Cipta.

Trianto. 2010. Menndesain model pembelajaran inovatif-progresif, Jakarta Kencana.

Hasibuan, Lias. 2010. Kurikulum dan Pemikiran Pendidikan, Jakarta: Gaung Persada Press.

Rusman, 2012. Manajemen Kurikulum, Jakarta Rajawali Pers.

Sanjaya, Wina, 2008, Kurikulum dan Pembelajaran, Jakarta: Kencana. 